\title{
Perasaan Anak yang Lulus di Era Covid-19
}

\author{
Amalia Fitriyana \\ Program Studi Psikologi Fakultas Kedokteran Universitas Lambung Mangkurat \\ Jalan Ahmad Yani Km 36, Banjarbaru, Kalimantan Selatan 70714 \\ E-mail : 2010914220037@mhs.ulm.ac.id
}

\begin{abstract}
Abstrak
Penelitian ini bertujuan untuk mencari tahu apa perasaan peserta didik ketika Ujian Nasional dihapuskan pada tahun akhir pembelajaran mereka. Penelitian ini juga mentitik beratkan pada pembelajaran secara daring melalui rumah akibat wabah Covid-19 dan mencari tahu apa saja dampaknya jika peserta didik harus menghadapi pembelajaran melalui rumah. Ketika wabah terjadi, semua sistem Pendidikan dilaksanakan dirumah, dan kebijakan-kebijakan pemerintah dilaksanakan. Ujian Nasional yang seharus dilaksanakan para siswa dibatalkan dan memberi dampak tersendiri bagi siswa tersebut, apalagi bagi mereka yang telah mempersiapkannya jauh-jauh hari. Penelitian ini juga mencari sisi positif apa yang ada ketika Ujian Nasional tersebut dihapus, khususnya bagi psikis sang anak, maupun Pendidikan secara keseluruhan.
\end{abstract}

Kata kunci : Daring, Ujian Nasional, Perasaan Anak, Covid-19.

\begin{abstract}
This study aims to find out what students feel when the National Examination is abolished at the end of their learning year. This research also focuses on learning online through the home due to Covid-19 and finding out what the effects will be if students have to face learning at home. When an outbreak occurs, all education systems are implemented at home, and government policies are implemented. The National Examination that was supposed to be carried out by students was canceled and had a special impact on these students, especially for those who had prepared it in advance. This research also looks for the positive side of what existed when the National Examination was removed, especially for the child's psychology, as well as for education as a whole.
\end{abstract}

Keywords: Online, National Examination, Children's Feelings, Covid-19.

\section{PENDAHULUAN}

Update terakhir Covid-19 di Indonesia pada tanggal 24 November 2020 dikabarkan sudah mencapai lebih dari lima ratus ribu jiwa yang positif dan sembuh lebih dari empat ratus ribu jiwa. untuk kurva jumlah positif digambarkan dengan kurva naik sedangkan untuk jumlah sembuh digambarkan dengan kurva turun oleh Komisi Penanganan Covid-19 dan Pemulihan Ekonomi Nasional (KPC PEN, 2020) per 24 November 2020.

Dari data tersebut dapat kita simpulkan bahwa Covid-19 masih banyak 
terkonfirmasi positif dan terdapat penurunan jumlah kesembuhan. Walaupun panduan pemerintah tentang kebiasaan baru sudah dihimbau dimana-mana tetap saja kecenderungan untuk melanggar di lingkungan masyarakat masih cukup tinggi. Banyak sektor yang terdampak oleh Covid19 beberapa diantaranya ialah sektor perekonomian, perdagangan, dan Pendidikan. (Boer et al., 2020). Pada sektor Pendidikan, proses belajar mengajar terhambat dan cukup terdampak akibat wabah Covid-19 (Purwanto et al., 2020).

Pemerintah mengumumkan proses belajar mengajar dimulai sejak pertengahan bulan Maret, seluruhnya diadakan di rumah atau pembelajaran sistem daring. (Dwi, 2020 dalam Abbas \& Erliyani, 2020). Banyak sekolah-sekolah yang terdampak akan hal ini, khususnya Pendidikan formal Indonesia di tingkat SD/MI, SMP/MTs, dan SMA/MA bahkan PT. Murid-murid yang seharusnya akan menghadapi Ujian Nasional harus menunda lagi pembelajaran akhir mereka di sekolah dan melanjutkannya di rumah. (Saleh, 2020).

Pendidik maupun pelajar semua melaksanakan pembelajaran melalui rumah. Setelah tidak lama kebijakan tersebut muncul, pada tanggal 24 Maret 2020 kebijakan baru keluar kembali dari Presiden Indonesia, Joko Widodo, Melalui Surat Edaran Menteri Pendidikan dan Kebudayaan Nomor 4 Tahun 2020, setelah mengadakan rapat terbatas dengan Kemendikbud, bahwasannya Ujian Nasional dihapuskan akibat dari Covid-19 yang merajalela di Indonesia.

Ujian Nasional pada dasarnya menilai hasil akhir dan mengabaikan bagaimana proses yang dijalani siswa. (Sinambela et al., 2020) siswa sering merasakan dampak akibat ujian tersebut secara psikis (Sinambela et al., 2020). Lalu karena terdampak Covid-19, keseluruhan siswa sekolah baik SD/MI, SMP/MTs, maupun SMA/MA tidak ada yang mengadakan Ujian Nasional. Hal ini tentu saja berdampak pada siswa yang mengalaminya. Tulisan ini saya fokuskan pada dampak atau perasaan yang dirasakan siswa ketika Ujian Nasional tersebut ditiadakan di tahun akhir sekolah mereka. Pemerintah juga akhirnya mengeluarkan kebijakan terkait mekanisme kelulusan para siswa.

Berdasarkan ketetapan Pemerintah dalam Surat Edaran Menteri Pendidikan dan Kebudayaan Nomor 4 Tahun 2020 Nilai akhir kelulusan hanya ditentukan oleh US (Ujian Sekolah) yang dilaksakanakan secara Online atau aternatif lain sesuai sekolah masing-masing.

Hal ini tentunya jika ditilik lebih dalam berdampak pada anak secara individu maupun sekolah atau kampus keseluruhan. Pada umumnya hasil belajar seorang anak dipengaruhi oleh kondisi 
fisik, bakat, minat, motivasi, emosi, kemampuan kognitif, juga secara eksternal yakni lingkungan alami, dan lingkungan sosial (Mattiro, 2020). Maka dari itu apabila lingkungan saat ini sedang terdampak Covid-19 maka hasil belajar anak juga terpengaruh.

Tidak hanya itu, keadaan para siswa atau pun mahasiswa pasti berubah, terkhusus secara psikis (Dewi, 2020). Bisa dari minat, motivasi, emosi, maupun kemampuan kognitifnya. Perasaan anak yang sering dilontarkan istilah "Angkatan Covid" pun pasti berbeda. Hingga timbul kecemburuan antara mereka yang terdampak wabah Covid-19 terpaksa menghadiri perpisahan atau wisuda secara online dengan mereka yang sudah terlebih dahulu lulus sebelum masa Covid-19.

\section{METODE PENELITIAN}

Penelitian ini menggunakan telaah literatur atau literature journal berdasarkan dengan urutan pendahuluan, metode penelitian, diskusi dan terakhir kesimpulan. (Shadiqi et al., 2020) Adapun jurnal-jurnal yang penulis cari adalah jurnal dengan kata kunci "Dampak dari Pendidikan Akibat Pandemi Covid-19”. Jurnal dicari dengan menggunakan PsycINFO karena dianggap lebih efektif untuk mencari database psikologi yang relevan (Shadiqi et al., 2020). Penulis juga menggunakan Google
Scholar untuk mencari penelitian yang berhubungan dengan Pendidikan saat ini. Jurnal yang dipakai menitikberatkan pada aspek Pendidikan di tengah wabah virus Corona. Terutama pada Pendidikan formal yang saat ini sedang berjalan beradaptasi dengan pandemi. Selain menitikberatkan pada Pendidikan, penulis juga menghubungkannya dengan keadaan psikologis seorang anak ketika menghadapi pembelajaran daring seperti ini, terkhusus bagi anak atau mahasiswa yang lulus pada tahun mewabahnya Covid-19.

Telaah yang penulis fokuskan meniti lebih dalam pada bagian dampak psikis juga perasaan seseorang ketika harus lulus secara terpaksa tanpa ada ujian kemudian langsung melanjutkan pendidikan ke jenjang selanjutnya. Kemudian penulis menuliskannya secara bertahap. Kecepatan menuliskan sebuah informasi dan memprosesnya lebih lamban jika dibanding menuliskannya hanya dikepala saja (Abbas, 2020). Oleh karena itu menuliskannya secara bertahap mengeluarkan apa yang dipikirkan penting untuk dilakukan menyesuaikan dengan telaah yang dilakukan.

\section{PEMBAHASAN}

\section{Pembelajaran di Masa Covid-19}

Pembelajaran selama pandemi Covid19 baik siswa maupun mahasiswa dilaksanakan secara daring, seluruh guru 
maupun dosen dituntut untuk bisa memberikan pengajaran yang berkolaboratif dan efektif walaupun secara daring. (Fatimah et al., 2020)

Belajar dengan merdeka menjadi salah satu metode pembelajaran yang dikemukakan oleh Menteri Pendidikan Nadiem Makarim (Saleh, 2020). Dalam hal ini merdeka belajar artinya anak-anak penting untuk merasakan kebahagiaan ketika belajar agar pengeluarannya menghasilkan generasi yang pintar dalam menganalisis diluar dari kemampuannya menghafal pelajaran (Saleh, 2020).

Di kala pandemi ini mahasiswa maupun siswa dituntut selain bisa merdeka belajar dengan Bahagia, mereka juga dituntut untuk mampu membawa diri dalam laju teknologi, karena saat PSBB (Pembatasan Sosial Berskala Besar) ini mereka harus menggunakan aplikasi-aplikasi pendukung belajar secara daring. Seperti video conference, zoom meeting, dan Google meeting (Rahman, 2020 dalam Abbas \& Erliyani, 2020). Studi kolaboratif sangat diperlukan pada masa-masa seperti ini. Materi dan metode belajar harus bisa divariasi secara kreatif oleh guru maupun dosen untuk meningkatkan daya tarik peserta didik selama krisis Covid-19 (Mansyur, 2020). Materi juga harus memuat informasi-informasi penting tentang wabah Covid-19. (Saleh, 2020).

\section{Dampak Bagi Anak Lulusan 2020}

Selain pembelajaran secara daring, anak-anak pada tingkat akhir pun terdampak, karena mereka mengikuti kebijakan pemerintah yakni lulus pada saat pandemi tanpa adanya Ujian Nasional. Ujian Nasional dihapuskan oleh pemerintah untuk menjaga para siswa dari virus corona (Sinambela et al., 2020). Ujian Nasional pada umumnya dinilai untuk mengukur kemampuan peserta didik (Abdullah, 2017 dalam Sinambela et al., 2020).

Melalui beberapa data dari kajian jurnal yang dilakukan oleh Sinambela, Suhada, \& Susilo (2020) terdapat setidaknya tiga perasaan yang dirasakan oleh anak-anak peserta didik yang harus batal Ujian Nasional. Diantaranya sebagai berikut, 1.) Takut tidak bisa memasuki jenjang Pendidikan selanjutnya, 2.) Merasakan akibat psikis berupa kesedihan dan kekecewaan karena telah belajar banyak untuk Ujian Nasional, 3.) Terpaksa karena jika harus Ujian Nasioanal, bisa membahayakan diri sendiri.

Dari beberapa data diatas dapat dimaknai bahwa anak merasakan beberapa dampak yang negatif akibat dari penghapus Ujian Nasional.

Dari data yang pertama, mereka merasa takut jika tidak ada Ujian Nasional, maka sulit akan masuk sekolah lanjutan, sebagaimana (Alawiyah, 2020) 
mengatakan Hasil Ujian Nasional ikut andil dalam menentukan kelulusan siswa pada sekolah lanjutan. Masyarakat sekitar juga mengganggap bahwa Ujian Nasional menentukan kelulusan seseorang, maka banyak orang tua yang mendorong anaknya agar belajar giat agar mendapat hasil yang baik (Mahmuda, 2017).

Kemudian untuk data yang kedua dapat dikatakan bahwa peserta didik merasakan sedih dan kecewa akibat persiapan mereka untuk Ujian Nasional terbuang begitu saja. Mereka mengaku sudah mengikuti bimbel, dan pembelajaran tambahan dari sekolah khusus untuk Ujian Nasional (Sinambela et al., 2020). Siswa pada data kedua merasakan akibat psikis berupa ketakutan tidak dapat melanjutkan pendidikannya, padahal ini cukup penting untuk dirinya.

Lalu pada data yang ketiga, peserta didik juga mengaku terpaksa dengan penghapusan Ujian Nasional demi kebaikan Bersama,karena jika harus Ujian Nasional ditakutkan Covid-19 lebih merajalela. Seseorang yang mempunyai penyakit menular, bisa menularkan penyakitnya ke orang lain di sekitarnya, tanpa terlihat ada gejala pada dirinya. (Darmawan, 2016)

Dari data-data di atas, diketahui bahwa peserta didik merasa kecewa karena harus menutup usaha mereka tanpa ujian, ujian dihapus dan mereka hanya lulus dengan nilai Ujian Sekolah yang dilaksanakan dengan kebijakan sekolah masing-masing, padahal Ujian Nasional diperuntukkan menilai hasil akhir siswa yang telah belajar selama tiga tahun dan menjadi patokan peserta didik untuk mendapatkan Pendidikan selanjutnya. Pendidikan adalah hal penting untuk kehidupan, menjadi pedoman untuk menghadapi masa yang akan datang. (Amini et al., 2019).

\section{Keberlanjutan}

\section{Pendidikan}

\section{Akibat Penghapusan Ujian Nasional}

Para siswa akhirnya melaksanakan Ujian Sekolahnya masing-masing di masa Covid-19, sesuai kebijakan pemerintah pada Surat Edaran Menteri Pendidikan dan Kebudayaan Nomor 4 Tahun 2020. Ujian sekolah tidak dilaksanakan secara langsung luring, melainkan secara daring, bisa dengan tes daring atau menggunakan sistem lain seperti penugasan, atau menggunakan capaian siswa sebelumnya pada prestasi maupun rapor. Tidak boleh diadakan tes apapun yang mengundang kerumunan, kecuali sebelum beredarnya Surat Edaran tersebut, pada tanggal 24 Maret 2020.

Akhirnya untuk melaksanakan penerimaan siswa baru, siswa hanya dimintai hasil rapor pada semester satu hingga lima saja, sebelum terjadinya pandemi Covid-19. Pemerintah juga membuat portal khusus yakni Rumah 
Belajar pada website Kemendikbud untuk belajar mandiri di rumah bagi siswa secara daring (Pujilestari, 2020). Siswa dituntut untuk mampu memainkan IT (Informasi dan Teknologi) di rumahnya masingmasing. Kemajuan Teknologi yang harus dikuasai ialah bentuk-bentuk pembelajaran yang dipakai tenaga pendidik para siswa masing-masing, seperti misalnya portal $e$ learning yang disediakan institusi mereka.

Selain kemampuan IT yang memadai, para siswa juga diharapkan mampu untuk mempertahankan diri masing-masing di rumah untuk tidak keluar rumah, berinteraksi dengan orang lain, dan menghadapi stress sendiri dirumah karena pembelajaran yang cukup melelahkan di rumah (Tanaputra, 2020, dalam Abbas \& Erliyani, 2020). Pada awalnya rasa kekecewaan menyelimuti para siswa karena persiapan Ujian Nasional harus terkubur begitu saja. Namun kemudian, siswa menghadapi stress sendiri ketika belajar hanya bersama device nya masing-masing dengan tumpukan tugas yang lebih banyak lagi. (Jesica, 2020 dalam Abbas \& Erliyani, 2020). Bentuk efikasi diri yang tinggi dapat mengurangi stress para siswa dalam menghadapi pembelajaran yang cukup hectic. (Afnan et al., 2020) Selain efikasi diri yang tinggi, para siswa juga bisa menghilangkan stress sekaligus melatih berpikir saat belajar di rumah dengan meningkatkan kecerdasan adversitasnya.
Kecerdasan adversitas diyakini mampu mengurangi kecemasan yang disebabkan oleh suasana hati, sehingga membuat peserta didik tangguh dan gigih ketika cemas saat belajar di rumah (Arman, 2019).

Beberapa Dampak positif dari penghapusan Ujian Nasional dari siswa dan dampak positif pembelajaran di rumah adalah Siswa jadi tidak perlu lagi memutar otak untuk melaksanakan Ujian Nasional dan memenuhi target penilaian sekolah nya masing-masing pada Ujian Nasional. Ujian Nasional dipandang dapat menilai bagaimana mutu Pendidikan di sekolah peserta didik (Tjalla, 2010). Sehingga peserta didik hanya tinggal mempersiapkan Pendidikan lanjutannya saja. Kemudian dampak positif pembelajaran dirumah ialah, berkembangnya IT di dunia Pendidikan, peran orang tua sebagai guru di rumah juga terasah, sebagaimana Ahsani (2020) mengatakan ketika ada di rumah maka orang tualah yang berperan membimbing anaknya, dukungan dan semangat dari orang tua penting untuk menjaga euphoria anak dalam belajar.

\section{KESIMPULAN}

Perasaan anak ketika harus menutup akhir sekolah mereka tanpa euphoria yang seharusnya memang menyimpan kekecewaan tersendiri bagi sang peserta didik, karena gambaran akhir yang mereka harapkan tidak seharusnya seperti itu. Tetapi mau bagaimana lagi, wabah yang 
sedang melonjak di Indonesia bahkan dunia, yakni pandemi Covid-19, membuat semua sektor yang ada harus ditunda perkembangannya.

Pendidikan merupakan sektor yang terdampak akan hal ini. Banyak siswa yang harus menutup usaha untuk Ujian Nasionalnya dengan begitu saja, tanpa ada memberi output pada usaha yang telah dilakukannya. Terlepas dari itu semua masih ada dampak-dampak positif yang mereka dapatkan, salah satunya mereka bisa menyiapkan keperluan sekolah lanjutannya dengan lebih mudah tanpa harus mengikuti ujian-ujian lainnya, hanya mengandalkan hasil rapor selama lima semester.

Penelitian ini tentunya perlu dikembangkan, bisa dengan mengembangkan pada subjek yang lebih luas ataupun ranah yang lebih mendalam lagi.

\section{DAFTAR PUSTAKA}

Abbas, E. W. (2020). Ersis Writing Theory: Cara Mudah Menulis.

Abbas, E. W., \& Erlyani, N. (2020). Menulis di Kala Badai Covid-19.

Afnan, A., Fauzia, R., \& Tanau, M. U. (2020). HUBUNGAN EFIKASI DIRI DENGAN STRESS PADA MAHASISWA YANG BERADA DALAM FASE QUARTER LIFE CRISIS. Jurnal Kognisia: Jurnal Mahasiswa Psikologi Online, 3(1), 23-29.
Ahsani, E. L. F. (2020). Strategi Orang Tua dalam Mengajar dan Mendidik Anak dalam Pembelajaran At The Home Masa Pandemi Covid-19. Al Athfal: Jurnal Kajian Perkembangan Anak dan Manajemen Pendidikan Usia Dini, 3(1), 37-46.

Alawiyah, F. (2015). Perubahan kebijakan ujian nasional (studi pelaksanaan ujian nasional 2015). Jurnal Aspirasi, 6(2), 189202.

American Psychological Association. (2020). Publication manual of the American Psychological Association (7th ed.). American Psychological Association.

Amini, M., Mayangsari, M. D., \& Zwagery, R. V. (2020). Hubungan antara Kemandirian Belajar dengan Komitmen Tugas pada Mahasiswa $\quad$ Program Studi Psikologi. Jurnal Kognisia: Jurnal Mahasiswa Psikologi Online,2(2), 149152.

Arman, J., Hidayatullah, M. S., \& Mayangsari, M. D. (2020). PERANAN KECERDASAN ADVERSITAS TERHADAP KEMAMPUAN BERPIKIR KRITIS PADA MAHASISWA YANG AKTIF ORGANISASI DI FAKULTAS KEDOKTERAN UNIVERSITAS LAMBUNG MANGKURAT. Kognisia prodi Psikologi FK ULM, 2(1), 42-50.

Boer, K. M., Pratiwi, M. R., \& Muna, N. (2020). Analisis Framing Pemberitaan Generasi Milenial dan Pemerintah Terkait 
Covid-19 di Media Online. Communicatus: Jurnal Ilmu komunikasi, 4(1), 85-104.

Darmawan, A., \& Epid, M. (2016). Epidemiologi penyakit menular dan penyakit tidak menular. JAMBI MEDICAL JOURNAL" Jurnal Kedokteran dan Kesehatan", 4(2).

Dewi, R. S., Ekaputri, F. K., Rachmah, D. N., \& Tanau, M. U. (2019). Effectiveness of Student-Centered Learning to Increase Learning Motivation of Students in Inventory Assessment Class. Researchers World, 10(2), 14.

Fatimah, F., Rajiani, S., \& Abbas, E. (2020). Cultural and individual characteristics in adopting computer-supported collaborative learning during covid-19 outbreak: Willingness or obligatory to accept technology?. Management Science Letters, 11(2), 373-378.

Mahmuda, M. (2017). Analisis problematika moratorium ujian nasional terhadap peningkatan mutu pendidikan. Prosiding Seminar Nasional \& Temu Jaringan Peneliti, 1(2), 202-214.

Mansyur, A. R. (2020). Dampak COVID-19 Terhadap Dinamika Pembelajaran Di Indonesia. Education and Learning Journal, 1(2), 113-123.

Mattiro, S. (2019). PENGETAHUAN LOKAL IBU TENTANG PENTINGNYA GIZI DAN SARAPAN PAGI BAGI ANAK. PADARINGAN (Jurnal
Pendidikan Sosiologi Antropologi), 1(1), 111.

Pujilestari, Y. (2020). Dampak Positif Pembelajaran Online Dalam Sistem Pendidikan Indonesia Pasca Pandemi Covid-19. 'ADALAH, 4(1).

Purwanto, A., Pramono, R., Asbari, M., Hyun, C. C., Wijayanti, L. M., \& Putri, R. S. (2020). Studi Eksploratif Dampak Pandemi COVID-19 Terhadap Proses Pembelajaran Online di Sekolah Dasar. EduPsyCouns: Journal of Education, Psychology and Counseling, 2(1), 1-12.

Saleh, M. (2020, May). Merdeka Belajar di Tengah Pandemi Covid-19. In Prosiding Seminar Nasional Hardiknas (Vol. 1, pp. 51-56).

Saturrosidah, A., Mayangsari, M. D., \& Hidayatullah, M. S. (2020). PENGARUH KELEKATAN DENGAN ORANGTUA TERHADAP KECERDASAN ADVERSITAS PADA REMAJA KORBAN PERCERAIAN. Kognisia prodi Psikologi FK ULM, 1(2), 21-27.

Shadiqi, M. A., Hariati, R., Hasan, K. F. A., I'anah, N., \& Al Istiqomah, W. (2020). Panic buying pada pandemi COVID-19: Telaah literatur dari perspektif psikologi. Jurnal Psikologi Sosial.

Shadiqi, M. A., Muluk, H., \& Milla, M. N. (2019). Experiment replication: A proposed solution for developing psychological research in Indonesia. ANIMA Indonesian Psychological Journal, 33(4). 
Sinambela, P. N., Suhada, S. N., \& Susilo, G.

S. (2020). Analisis Mengenai Dampak

Penghapusan Ujian Nasional Terhadap Kelulusan Peserta Didik Jenjang Smp Di Era Pandemik Covid-19. Diskusi Panel Nasional Pendidikan Matematika.

Tjalla, A. (2010). UN dan Peningkatan Mutu Pembelajaran di Sekolah. FIP Universitas Negeri Jakarta: Makalah.

Yuwanto, D., Mayangsari, M. D., \& Anward, H. H. (2016). Hubungan efikasi diri dengan kesiapan kerja pada mahasiswa yang sedang mempersiapkan skripsi. Jurnal Ecopsy, 1(4). 